症例報告

早期診断により多臓器不全から救命し得た劇症型抗リン脂質抗体症候群の 1 例

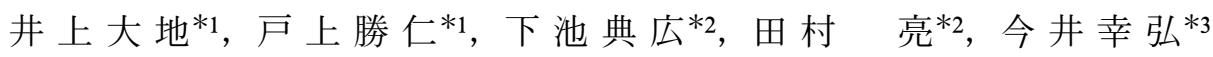 \\ 木村隆治*1, 下地園子*1, 森美奈子*1, 永井雄 也*1, 田端淑 恵*1 \\ 松下章子*1, 永井謙一*1, 高橋隆 幸*1
}

\title{
Early diagnosis and successful treatment of catastrophic antiphospholipid syndrome complicated by multiple organ failure
}

\author{
Daichi INOUE*1, Katsuhiro TOGAMI ${ }^{* 1}$, Norihiro SHIMOIKE*2, Ryo TAMURA ${ }^{* 2}$, Yukihiro IMAI*3, \\ Takaharu KIMURA $^{* 1}$, Sonoko SHIMOJI ${ }^{* 1}$, Minako MorI ${ }^{* 1}$, Yuya NAGAI ${ }^{* 1}$, Sumie TABATA*1, \\ Akiko MATSUSHITA ${ }^{* 1}$, Kenichi NAGAI ${ }^{* 1}$ and Takayuki TAKAHASHI ${ }^{* 1}$ \\ ${ }^{*}$ Department of Hematology and Clinical Immunology, Kobe City Medical Center General Hospital, Kobe, Japan \\ ${ }^{*}$ Department of Surgery, Kobe City Medical Center General Hospital, Kobe, Japan \\ ${ }^{*}$ Department of Clinical Pathology, Kobe City Medical Center General Hospital, Kobe, Japan
}

(Received September 19, 2009)

summary

A 50-year-old woman was emergently admitted because of rapidly progressive unconsciousness, renal failure, hepatic dysfunction, hemolytic anemia, thrombocytopenia, and high-grade fever in July, 2008. Based on clinical and laboratory findings, we made a tentative diagnosis of thrombotic thrombocytopenic purpura (TTP) and immediately initiated the plasma exchange (PE). Despite the PE, she developed panperitonitis due to multiple intestinal perforation and massive splenic infarction within a week after the admission. Thrombosis of arterioles at perforated portion in the resected small and large intestines was histologically confirmed. Therefore, we made a definite diagnosis of catastrophic antiphospholipid syndrome (CAPS) based on the presence of antiphosphatidylserine-prothrombin complex antibodies (aPS/PT) throughout the course and lupus anticoagulant that was revealed positive on one occasion, and multiple thrombotic lesions. The underlying disease of CAPS appeared to be lupus erythematosus because of her clinical history and laboratory findings such as persistent leukopenia. Although it has been reported that CAPS causes systemic thrombosis at microvessels mostly within a week from the onset and the mortality rate in this disorder is as high as $50 \%$, we successfully treated her in combination with high-dose corticosteroid, anticoagulation, concentrated human IgG, surgical procedures, and hemodialysis in addition to PE. Early diagnosis of CAPS and immediate start of PE may have contributed to the successful treatment.

Key words catastrophic antiphospholipid syndrome; autoimmune hemolytic anemia; antiphosphatidylserineprothrombin complex antibodies; systemic thrombosis

抄 録

症例は 50 歳女性.急激に進行する意識障害, 腎不全, 肝機能障害, 溶血性貧血, 血小板減少, 発熱のために 2008 年 7 月, 当院に救急搬送された。病歴から血栓性血小板減少性紫斑病が疑われ，血漿交換を開始したが，入 院後 1 週間以内に, 血栓による腸管穿孔, 脾梗塞を併発し, さらに, フォスファチジルセリン依存性抗プロトロン ビン抗体（aPS/PT）が陽性であったことから，劇症型抗リン脂質抗体症候群（CAPS）と考えられた。他の抗リ ン脂質抗体は，ループスアンチコアグラント（LA）が経過中 1 度だけ陽性となった。基礎疾患は，病歴・検査所 見から全身性エリテマトーデス（SLE）が疑われた．CAPSは，過半数例で死の転帰をとるが，腸管穿孔に対して は，腸切除などの外科的処置を施行し，また，高容量のステロイド療法とヘパリンやワーファリンによる抗凝固療 法を血漿交換に併用し，救命に成功した.CAPS は，短期間で全身の微小血管に血栓をきたす予後不良な疾患であ り，現在の診断基準には aPS/PT が含まれていないものの，aPS/PT は LA の存在や血栓症と強い相関がある. 本 例は診断に難渋したものの, 臨床経過, 組織学的な血栓の証明, 抗リン脂質抗体の存在から, 早期に治療介入で き，また，aPS/PT 抗体価が病勢を反映して低下した．貴重な症例と考えここに報告する.

\footnotetext{
*1神戸市立医療センター中央市民病院免疫血液内科,

*2神戸市立医療センター中央市民病院外科，*3神戸市

立医療センター中央市民病院臨床病理科
} 


\section{緒言}

抗リン脂質抗体症候群 (antiphospholipid syndrome, APS）は， $\beta_{2}$-glycoproteinI 依存性抗カルジ オリピン抗体 $\left(\mathrm{aCL} / \beta_{2} \mathrm{GPI}\right)$ ，ループスアンチコア グラント（LA）などの抗リン脂質抗体（antiphospholipid antibodies, aPL) が存在することによ り，各種動静脈血栓症や習慣流産などの妊娠合併症 を来たす自己免疫疾患である11 。近年，APS の診断 基準には含まれていないが，抗プロトロンビン抗体 も LA の存在や血栓症と強い相関があることが明ら かとなり注目されている2). 一方，APSの中に短期 間で複数の臓器の微小血管に血栓を来たす予後不良 の一群が存在し, 劇症型抗リン脂質抗体症候群 (catastrophic antiphospholipid syndrome, CAPS) と呼ばれている ${ }^{3)}$.今回, 我々は, 抗プロトロンビ ン抗体の検出から CAPS と診断し，血漿交換，又 テロイド投与，抗凝固療法，外科的手術などにより 救命できた症例を経験したので，報告する.

\section{症例}

症 例 : 50 歳女性

主 訴：発熱および意識障害

既往歴：20 歳頃から白血球低值を指摘されてい た。これまでに 2 回妊娠, 1 回流産 (初期流産).
現病歴 : 2008 年 4 月中旬より動悸や労作時の呼 吸苦を自覚していた。 2008 年 6 月 28 日，39度の発 熱が出現し, 動悸, 倦怠感の増悪のため, 2 日後に 近医を受診したところ，著明な貧血（ $\mathrm{Hb} 1.9 \mathrm{~g} / \mathrm{dl} ）$ と血小板減少, 肝酵素 ·胆道系酵素上昇を指摘さ れ, 緊急入院となり赤血球濃厚液を計 10 単位輸血 された。しかし，意識レベルの低下を認め， 2008 年 7 月 3 日, 血栓性血小板減少性紫斑病（thrombotic thrombocytopenic purpura ; TTP) の疑いのも と当院へ緊急搬送となった。

入院時現症：身長 $163 \mathrm{~cm}$, 体重 $48 \mathrm{~kg}$, 血圧 112 $/ 50 \mathrm{mmHg}$, 脈拍 117 回/分, 体温 $39.0^{\circ} \mathrm{C}$. 意識 ベル JCS 200, $\mathrm{SpO}_{2} 96 \%$ （6L マスク）. 瞳孔正常, 対光反射は異常なし. 眼球結膜黄染し, 眼瞼結膜は 貧血様。口腔内血液貯留あり。右季肋下に圧痛㐫 り。背面に網状皮斑を認めた。

入院時検査所見（表 1）: 汎血球減少，白血球の 左方移動, 赤芽球の出現を認め, 網状赤血球抢よび 網状血小板が上昇していた。破确赤血球は $0.4 \%$, 直接・間接 Coombs 試験は陽性，ハプトグロビン は感度以下であった。 また, 血液凝固異常, AST, ALT, LDH, T-Bil の著増が顕著であった.ALT が 異常高值であり，LDH アイソザイムは 5 型が優位 （85\%）であったことから，これら生化学検査の異 常は肝障害が主体であると考えられた。しかし，溶

表 1 入院時血液検查所見

\begin{tabular}{|c|c|c|c|c|c|}
\hline \multirow{2}{*}{$\begin{array}{l}\text { Hematology } \\
\text { WBC }\end{array}$} & \multirow[b]{2}{*}{$2,400 / \mu \mathrm{l}$} & \multicolumn{2}{|c|}{ Serum chemistry } & \multicolumn{2}{|l|}{ Serology/Others } \\
\hline & & $\mathrm{TP}$ & $5.3 \mathrm{~g} / \mathrm{dl}$ & CRP & $3.1 \mathrm{mg} / \mathrm{dl}$ \\
\hline Myelo & $3 \%$ & Alb & $2.7 \mathrm{~g} / \mathrm{dl}$ & $\operatorname{IgG}$ & $1,380 \mathrm{mg} / \mathrm{dl}$ \\
\hline Meta & $5 \%$ & $\mathrm{~T}-\mathrm{Bil}$ & $6.3 \mathrm{mg} / \mathrm{dl}$ & $\operatorname{Ig} \mathrm{A}$ & $361 \mathrm{mg} / \mathrm{dl}$ \\
\hline Band & $64 \%$ & D-Bil & $3.3 \mathrm{mg} / \mathrm{dl}$ & $\operatorname{IgM}$ & $58 \mathrm{mg} / \mathrm{dl}$ \\
\hline Seg & $22 \%$ & AST & $9,666 \mathrm{IU} / 1$ & SIL2R & $2,270 \mathrm{U} / \mathrm{ml}$ \\
\hline Lym & $3 \%$ & ALT & $3,494 \mathrm{IU} / 1$ & ferritin & $23,540 \mathrm{ng} / \mathrm{ml}$ \\
\hline Mon & $3 \%$ & $\mathrm{LDH}$ & $18,077 \mathrm{IU} / 1$ & $\mathrm{Hp}$ & $<10 \mathrm{mg} / \mathrm{dl}$ \\
\hline $\mathrm{RBC}$ & $207 \times 10^{4} / \mu \mathrm{l}$ & ALP & $267 \mathrm{IU} / 1$ & BNP & \\
\hline $\mathrm{Hb}$ & $7.3 \mathrm{~g} / \mathrm{dl}$ & $\gamma$-GTP & $61 \mathrm{IU} / 1$ & 抗核抗体 & $\begin{array}{r}1,777 \mathrm{pg} / \mathrm{ml} \\
42.0\end{array}$ \\
\hline Hct & $20.7 \%$ & LAP & $105 \mathrm{IU} / 1$ & 抗 DNA 抗体 < & \\
\hline Ret & $8.7 \%$ & $\mathrm{ChE}$ & $145 \mathrm{IU} / 1$ & 抗 SS-A 抗体 & $\begin{array}{r}<5.0 \mathrm{IU} / \mathrm{ml} \\
131.9\end{array}$ \\
\hline Plt & $2.5 \times 10^{4} / \mu \mathrm{l}$ & CPK & $6539 \mathrm{IU} / 1$ & 抗 SS-B 抗体 & $(-)$ \\
\hline reti-PLT & $27 \%$ & AMY & $519 \mathrm{IU} / 1$ & 抗 Sm 抗体 & $(-)$ \\
\hline Coagulation & & BUN & $42 \mathrm{mg} / \mathrm{dl}$ & LA & $(-)$ \\
\hline $\mathrm{PT}$ & $31.0 \%$ & $\mathrm{Cr}$ & $2.31 \mathrm{mg} / \mathrm{dl}$ & $\mathrm{aCL} / \beta_{2} \mathrm{GPI}$ & $(-)$ \\
\hline APTT & $60.8 \mathrm{sec}$ & UA & $15.6 \mathrm{mg} / \mathrm{dl}$ & ADAMTS13 活性 & $16.3 \%$ \\
\hline Fibrinogen & $54 \mathrm{mg} / \mathrm{dl}$ & $\mathrm{Na}$ & $146 \mathrm{mEq} / 1$ & \multicolumn{2}{|l|}{ Inhibitor } \\
\hline D-dimer & $146.3 \mu \mathrm{g} / \mathrm{ml}$ & $\mathrm{K}$ & $3.3 \mathrm{mEq} / 1$ & 直接 Cooms 試験 & $(+)$ \\
\hline & & $\mathrm{Cl}$ & $107 \mathrm{mEq} / \mathrm{l}$ & \multicolumn{2}{|c|}{ 間接 Cooms 試験 $\quad(+)$} \\
\hline & & $\mathrm{NH}_{3}$ & $69 \mu \mathrm{g} / \mathrm{dl}$ & PA-IgG 210.2 & $210.2 \mathrm{ng} / 10^{7} \mathrm{pl}$ \\
\hline
\end{tabular}


血性貧血などにより修飾されたデータである可能性 も考えられた。 また，急性腎不全を合併しほぼ無尿 であった。その他，フェリチン，尿酸，CRP が高 值を示した. 自己抗体は，抗核抗体，抗 SS-A 抗体 が陽性であったが，LA， aCL $/ \beta_{2}$ GPI などは，入院 時陰性で，ADAMTS13 の活性は低下していたもの の，インヒビターは検出されなかった．補体は C3 $46 \mathrm{mg} / \mathrm{dl}, \mathrm{C} 47 \mathrm{mg} / \mathrm{dl}, \mathrm{CH} 50<10 \mathrm{U} / \mathrm{ml}$ と低值であ った（正常範囲は各々 65-135 mg/dl, 13-35 mg/dl, 29-48 U/ml). 各種肝炎ウイルスやヘルペス属ウイ ルスは検出されなかったが，入院時の血液培養よ り, 感受性良好な Staphylococcus aureus, Streptococcus salvarius が検出された.

入院後経過：経過を図 1 に示す.上述のと抢り, TTP の 5 徵を満たしており, 呼吸不全状態であっ たので人工呼吸管理とした。腎障害，尿量低下につ いては持続的血液濾過透析 (continuous hemodiafiltration；CHDF）を行い，第 1 病日より血漿交換 (plasma exchange；PE）を連日 5 日間施行した。 何らかの免疫異常を想定し，その改善を目的に methyl prednisolone (mPSL) (40 mg/day から開始 し，増量）を継続投与した。第 2 病日には意識レべ
ルの改善を認め，第3 病日にはほぼ清明となった。 肝腎機能と共に改善傾向を認め, PE/CHDF の効 果ありと判断した。

しかし, 第 6 病日に, 意識レベルが再増悪し, $\mathrm{CRP} 13.3 \mathrm{mg} / \mathrm{dL}$ と上昇, 腹部全体が板状硬となっ た. CT で，腹水，free air，完全脾梗塞（図 2) を 認めたため, 同日, 大量輸血の上, 緊急開腹手術を 施行したところ，便の混じった腹水が多量にみら れ, 回腸末端 $50 \mathrm{~cm}$ にわたり不可逆性の腸管壊死 を認めたので壞死部分を切除した。ささらに行結腸 にも径 $2.5 \mathrm{~cm}$ の穿孔を認め, 肛門側で $\mathrm{S}$ 状結腸を $15 \mathrm{~cm}$ 切除した. 回腸断端の口側々 $\mathrm{S}$ 状結腸肛門側 断端の 2 ヶ所に人工肛門を増設した。穿孔部の病理 組織では腸間膜, 腸管壁内の細血管に多数の微小血 栓を確認した（図 3)。第 1 病日の保存血清を検討 したところ, phosphatidylserine 依存性抗プロトロ ンビン抗体 (aPS/PT) が IgG, IgM ともに陽性で あったため，脾梗塞や腸管の多発穿孔を考元合わせ， CAPS と診断した。 入院時の CPK の著明高値は, CPK-MM が 99\% と優位であったため，CAPS によ る脾梗塞, 腸管梗塞だけでなく, 骨格筋の血流障害 を反映したものと考えられた。術後翌日（第 7 病日）

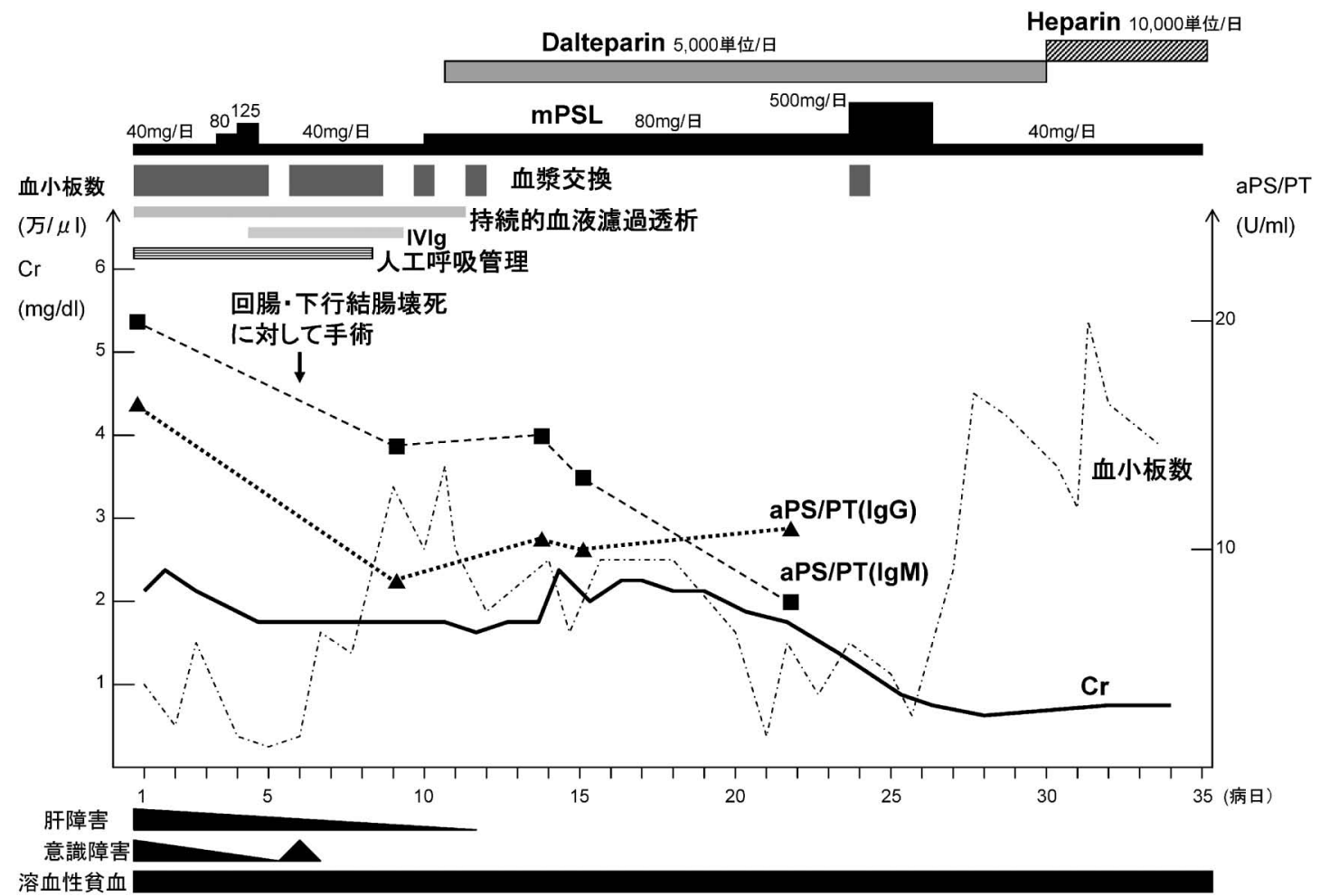

図 1 臨床経過

当院入院後, 速やかに血漿交換, ステロイド投与を行った。 また，人工呼吸管理や持続的血液濾過透析も施行した。第 6 病日 の外科的手術により, 腸管の血栓が証明され, また, 入院時の検体で aPS/PT が高值であったことから, 劇症型抗リン脂質症候 群と考え, 第 6 病日から IVIg (大量ガンマグロブリン投与), 第 12 病日より抗凝固療法も併用した. ステロイドはパルス量まで 増量したが，これらの併用により臨床症状，検査所見の安定を認めた。 

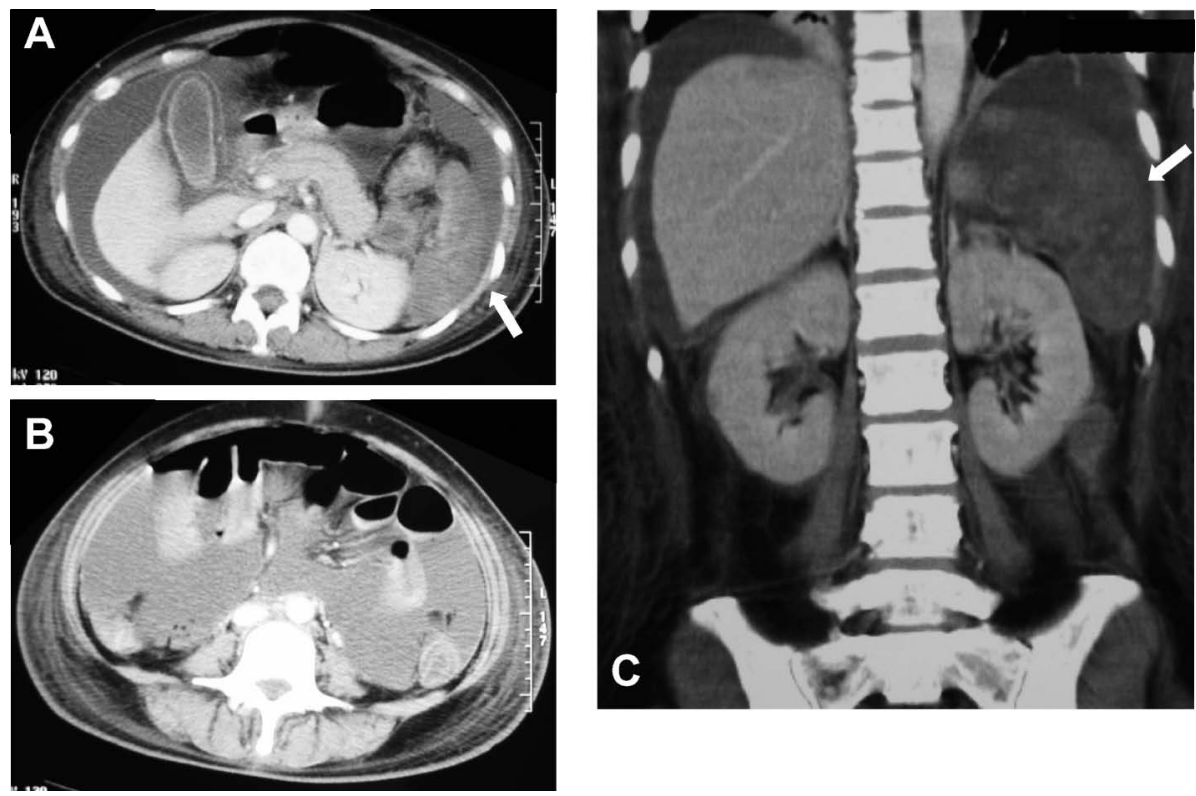

図 2 腹部造影 $\mathrm{CT}$ (第 6 病日)

多量の腹水と free air を認め (A, B), 脾蔵は造影されず (A, C, 矢印), 腸管穿孔と脾動脈レベルでの血栓と考えられた.
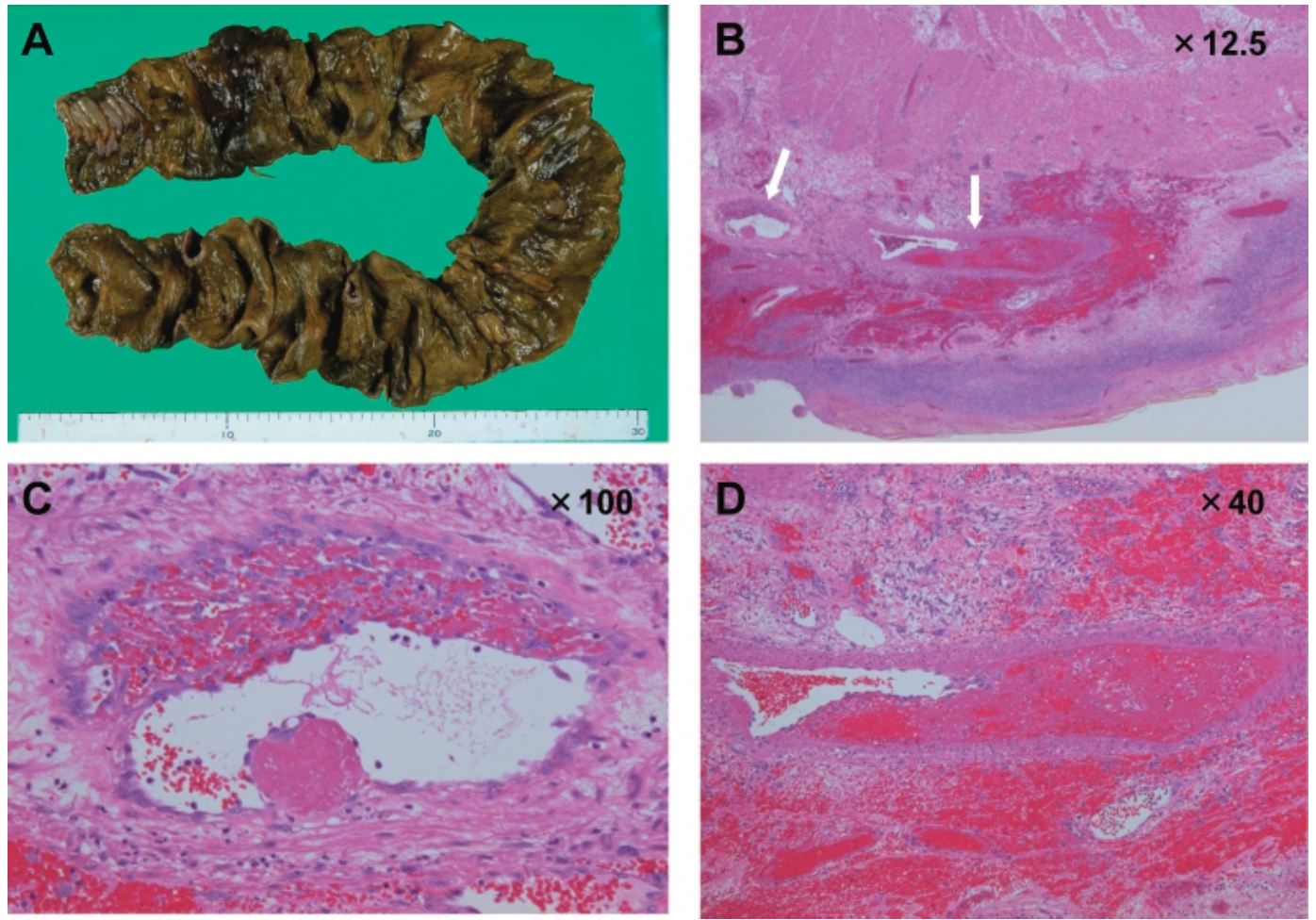

図 3 病理組織（回腸）

回腸切除標本は，壊死により，全体に黒色調（A) で，低倍では，腸管壁内の細血管内に微小血栓が顕著であり（B，矢印）， 粘膜固有層の壊死も認められた。拡大すると, 器質化血栓とフィブリン血栓の混在 $(\mathrm{C})$, フィブリンと赤血球による血栓（D） が確認できた。

より，3 日間 PE を施行したところ，意識レベル， 腎機能, $\mathrm{SpO}_{2}$ が改善し，CHDF は第 13 病日で終了， PE も残り第 12,14 ，打よび 27 病日で終了した。 また，手術当日より，自己抗体による赤血球・血小 板の破壊㐫進，あるいは，aPS/PT による血栓原性
を抑制するため，免疫グロブリン大量療法（IVIg， $20 \mathrm{~g} /$ 日， 5 日間）を施行した. 抗凝固療法として, 第 12 病日より低分子へパリン（Dalteparin）を 5,000 単位/日で開始したが，貧血と血小板減少が 遷延するため, Coombs 抗体や抗血小板自己抗体産 
生の抑制を目的に，第 26 病日より mPSL $500 \mathrm{mg}$ / 日を 3 日間パルス投与したところ，徐々に貧血およ び血小板減少の回復を認めた。その後, $40 \mathrm{mg} /$ 日 に減量し, 第 36 病日から prednisolone (PSL) 30 $\mathrm{mg} /$ 日の内服に切り替えた. PE や mPSL の投与に より, aPS/PT は低下傾向となり, 全身状態も抗体 価に合わせて改善した. しかし出血傾向は続き，そ の後, 梗塞脾に起因する広汎な腹腔内膿瘍を来たし たが，第 45 病日に脾摘術, 腹腔内ドレナージを施 行した。摘出した脾臓は全体が壊死し，一部が膿瘍 化していた。 以降, 抗生物質による腹腔内感染のコ ントロールと平行して, 第 30 病日から, ヘパリン 10,000 単位/日による抗凝固療法を継続した。第 90 病日よりワーファリンを開始し, PT-INR を 2 前後 でコントロールしたＰSLを $10 \mathrm{mg}$ まで減量する と, 自己免疫性溶血性貧血 (AIHA) の再燃 $(\mathrm{Hb}$ $5.5 \mathrm{~g} / \mathrm{dL}$ ) を認めたため, PSLを $30 \mathrm{mg} /$ day に増 量したところ緩やかに改善した. 以降, 再度減量し,

PSL $10 \mathrm{mg} /$ day を維持量とした。自己抗体に関し ては， $\mathrm{aCL} / \beta_{2} \mathrm{GPI}$ は常に陰性であったが，抗 DNA 抗体は陽性となり $(6.1 \mathrm{IU} / \mathrm{ml}$, 正常は 5 以下), LA は第 22 病日の検体で陽性であった。抗核抗体 は陰転化し, 補体は第 36 病日以降正常化したが, 抗 SS-A 抗体, 直接・間接 Coombs 試験は陽性の ままであった，筋力改善，與下機能改善を図り，第
176 病日に退院した。退院後は, 外来で, PSL 10 $\mathrm{mg} /$ 日とワーファリンによる抗凝固療法を続けてお り, 2009 年 7 月現在, CAPS の再燃は認めていな い. 今後, 全身状態の改善を待って腸管の再吻合術 を施行予定である.

\section{考察}

本症例は, 当初, TTP の 5 徵を全て満たしてお り, PEを開始としたが, 特徵的な経過から, CAPS を疑い, PE とステロイド, 抗凝固療法, 外科的手術により, 良好なコントロールが得られ た. CAPS と診断した根拠であるが, CAPS registry（http://www.med.ub.es/MIMMUN/FORUM/ CAPS.HTM）によると, 表 2 の診断基準が提唱さ れている，この症例では，LA は 1 回だけ陽性であ ったものの， $\mathrm{aCL} / \beta_{2} \mathrm{GPI}$ は常に陰性であった。し かし, 救急搬送時の検体では aPS / PT が, IgG, $\mathrm{IgM}$ ともに陽性であった。 $\mathrm{aPS} / \mathrm{PT} の$ 検出には phosphatidylserine 上にプロトロンビンを $\mathrm{Ca}^{2+}$ 存 在下に固相化した ELISA 法を用いた ${ }^{2)}$. aPS / PT は, APS の臨床症状や LA との関連が強いと報告 されている2)。この症例の臓器障害は, 中枢神経, 肝蔵, 腎臓, 脾臓, 腸管, 皮膚など多岐にわたり, これらが 1 週間以内に連続して発症しており, 腸管 穿孔部では小血管の閉塞が組織学的に確認された。

表 2 Preliminary Criteria for the Classification of Catastrophic APS

1 Evidence of involvement of three or more organs, sytems and/or tissues*

2 Development of manifestations simultaneously or in less than a week

3 Confirmation by histopathology of small vessel occulusion in at least one organ or tissue**

4 Laboratory confirmation of the presence of aPL (LA and/or aCL) $* * *$

* Usually, clinical evidence of vessel occlusions, confirmed by imaging techniques when appropriate. Renal involvement is defined by a $50 \%$ rise in serum creatinine, severe systemic hypertension $(>180 / 100 \mathrm{mmHg})$ and/or proteinuria $(>500 \mathrm{mg} / 24$ hours).

** For histopathological confirmation, significant evidence of thrombosis must be present, although vasculitis may coexist occasionally.

*** If the patient had not been previously diagnosed as having an APS, the laboratory confirmation requires that presence of aPL must be detected on two or more occasions at least 6 weeks apart (not necessarily at the time of the event), according to the proposed preliminary criteria for the classificaiton of definite APS [3].

Definite catastrophic APS :

- All 4 criteria

Probable catastropic APS :

- All 4 criteria, except for only two organs, system and/or tissue involvement.

- All 4 criteria, except for the absence of laboratory confirmation at least 6 weeks apart due to the early death of a patient never previously tested for aPL prior to the catastrophic event.

- 1,2 and 4

- 1, 3 and 4 and the development of a third event in more than a week but less than a month, despite anticoagulation. 
CAPS registry の診断基準には aPS/PT が含まれて おらず，確定には至らないものの，上述の理由によ り，本症例は CAPS に該当すると考元られる，山 崎らは，IgG 型 aPS/PT をCAPS の診断基準に追 加することを提唱している4). 腸管を除いて, 病理 学的な検索は行われていないものの, 表 2 の診断基 準に抢いては，血管閉塞の証明は一般的に画像検査 により行うとされ, 診断に必要な蔵器は 3 つ以上と 記載されている。 また，血清クレアチニン值の 50 \%以上の上昇で腎障害ありと判断するため，少なく とも, 腸管, 脾蔵, 腎蔵は血栓症によるものと考元 られ, 短期間での多臓器血栓の進行や aPS/PT の 存在を考慮すれば，中枢神経・皮膚病変なども血 栓によるものであったと推測される。CAPS と類似 の症状を来たす病態として，TTP，ヘパリン惹起 血小板減少症 (heparin-induced thrombocytopenia, HIT), 播種性血管内凝固症 (disseminated intravascular coagulation, DIC）があげられるが，破砕赤血 球が $0.4 \%$ と低值であり, ADAMTS-13 inhibitor が 陰性, ヘパリンの使用歴がない点より TTP や HIT の関与は否定的であった。この症例では D-dimer の上昇が顕著であり，敗血症によるDIC の修飾は 否定できない.CAPS では 20\%強の症例でDICを 併発するという報告もある5)。しかし，本例に抢け る, 短期間での多臓器血栓や aPS / PT の存在は, 敗血症やそれに伴うDIC の久では説明不可能と考 えられる。

CAPS の基礎疾患として，これまでの報告では， primay APS, SLE が 9 割近くを占める6 ${ }^{6}$.この症例 では, 血栓症の既往がなく, 10 週未満の流産が 1 回のみであるため, APS の臨床基準を満たさな い. 以前より白血球数が低值であり, 今回の入院時 の抗核抗体が陽性, 補体が低值, AIHA おょび自 己免疫性と考えられる血小板減少症を合併していた ことから，基礎疾患としてのSLE 類似の自己免疫 疾患である可能性が示唆される. 経過中に PSL 10 mg/day でAIHA が再然したものの, CAPS は増悪 しなかったことは興味深く, CAPS registry には 2009 年 7 月現在 300 例近い症例が登録されている にも関わらず，再発例は 10 例のみである.CAPS そのものの発症因子は $60 \%$ の症例で報告されてお り, 感染症や外科的処置が多(7). 搬送時に Staphylococcus aureus, Streptococcus salvarius によ る敗血症を合併しており，これが契機になったと考 えられるが，CAPSによる消化管虚血から， bac- terial translocation を来たした可能性も否定できな い。 また, 肝障害は, 自己免疫性肝炎の可能性々, CAPS による血流障害の可能性があるが, CAPS の 治療により, 速やかに正常化したこと, 全身性の血 栓傾向が顕著であったことを考慮すれば，肝障害も やはり, 微小血栓による血流障害と考えるのが妥当 であろう。

CAPS は過半数例で死の転帰をとるために ${ }^{8)}$, 重 症例では, 高容量のステロイド, ヘパリンによる抗 凝固療法, PE，IVIg などを併用することが推奨さ れている6). 予後不良因子としては, 腎障害, 脾梗 塞, 肺病変, SLEの存在, 副腎不全などが報告さ れているが7), この症例ではこのうちの多くを満た していた．治療として特に，PEを可及的速やかに 行うことが望ましいと考えられる. 本例では搬送 後, 直ちにPEを施行したが, このことにより血漿 中に存在する, interleukin (IL) $-1, \mathrm{IL}-6, \mathrm{TNF}-\alpha$ な ぞの, 種々のサイトカインと共に aPS/PT を除去 できたことが，良好な予後につながったと推測され る6,9). CAPS による腸管穿孔に対しても外科的手 術を比較的安全に施行でき, 手術によるCAPS の 増覀も認めなかった，さらに予後を改善する工夫と して, PEの置換液として, 凝固因子を大量に含む 新鮮凍結血漿の代替としてアルブミン製剤を用いる 方法10)や，抗 CD20 モノクローナル抗体である rituximab を用いて種々の抗体産生を阻害すること で，良好な成績を得たとの報告がある11,12)。免疫グ ロブリン大量療法の上乗せ効果は明らかでないが， 血小板減少を来たす症例には有効であるとの知見も あり6)，各種抗体が関与した本症例の改善に寄与し た可能性もある. 致死率の高いCAPS の治療最適 化には, さらなる評価が必要である.

CAPS は稀な疾患でありながら，本例のように， 急激な経過を辿るため, 迅速な診断, 加療が必要で ある.この症例では, aPS/PT を測定しなければ, TTP としての治療を継続し, ステロイド投与や抗 凝固療法の導入が遅延したものと考える. aPS $/ \mathrm{PT}$ を含む診断基準の整備や, 治療については今後の症 例の蓄積が待たれる.

謝 辞 : aPS/PT を測定して頂いた, 金沢大学大 学院医学系研究科細胞移植学 (血液内科) の山崎雅 英先生に深謝申し上げます. 


\section{文献}

1) Miyakis, S., et al. : International consensus statement on an update of the classification criteria for definite antiphospholipid syndrome (APS). J Thromb Haemost. 4 : 295-306, 2006.

2) Atsumi, T., et al. : Association of autoantibodies against the phosphatidylserine-prothrombin complex with manifestations of the antiphospholipid syndrome and with the presence of lupus anticoagulant. Arthritis Rheum. 43 : 1982-1993, 2000.

3) Asherson, R. A., et al. : Catastrophic antiphospholipid syndrome : international consensus statement on classification criteria and treatment guidelines. Lupus. 12 : 530-534, 2003.

4）山崎雅英：劇症型抗リン脂質抗体症候群. 日 本臨床免疫学会会誌 $28: 357-64,2005$.

5) Asherson, R. A., et al. : Disseminated intravascular coagulation in catastrophic antiphospholipid syndrome : clinical and haematological characteristics of 23 patients. Ann Rheum Dis. 64 : 943-946, 2005.

6) Cervera, R., et al. : Catastrophic antiphospholipid syndrome: lessons from the "CAPS Registry"--a tribute to the late Josep Font. Ann N Y Acad Sci. 1108 : 448-456, 2007.

7) Cervera, R., et al. : Validation of the prelimina- ry criteria for the classification of catastrophic antiphospholipid syndrome. Ann Rheum Dis. 64 : 1205-1209, 2005.

8) Erkan, D., et al. : Long term outcome of catastrophic antiphospholipid syndrome survivors. Ann Rheum Dis. 62 : 530-533, 2003.

9) Koschmieder, S., et al. : Combined plasmapheresis and immunosuppression as rescue treatment of a patient with catastrophic antiphospholipid syndrome occurring despite anticoagulation: a case report. Blood Coagul Fibrinolysis. 14 : 395-399, 2003.

10) Bortolati, M., et al. : Recovery from catastrophic antiphospholipid syndrome by a plasma exchange procedure : report of four cases and review of the literature. Autoimmun Rev. 8 : 297-301, 2009.

11) Nageswara Rao, A. A., et al. : Rituximab for successful management of probable pediatric catastrophic antiphospholipid syndrome. Pediatr Blood Cancer. 52 : 536-538, 2009.

12) Manner, H., et al. : Successful treatment of catastrophic antiphospholipid antibody syndrome (CAPS) associated with splenic marginal-zone lymphoma with low-molecular weight heparin, rituximab and bendamustine. Am J Med Sci. 335 : 394-397, 2008. 